\title{
PSYCHOLOGICAL PECULIARITIES OF SUBJECTIVE WELL-BEING OF RESIDENTS IN GERIATRIC HOMES
}

\author{
IRYNA HORBAL \\ iryska.ambivalence@gmail.com
}

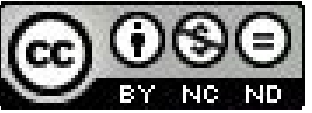

\begin{abstract}
The article is dedicated to the theme of subjective well-being of elderly people living in geriatric homes. Social and psychological peculiarities of life satisfaction of senior people were analysed in the works of Ukrainian and foreign authors. The research found life satisfaction of people who have a lack of social contacts is connected with the value orientations of hedonism and spirituality, hardiness, mental health and low sense of pain. These physiological, social and psychological components were generalized into the structure of subjective well-being.
\end{abstract}

Key words: subjective well-being, senior person, social deprivation, geriatric home, socialization.

Issues of human subjective well-being and life satisfaction become more relevant in terms of contemporary social transformation. Despite the growing number of studies of life satisfaction (Diener 1985, Argyle 2001, Куликов 2000, Шамионов 2004), this psychological phenomenon needs further consideration and clarification. The problems of life quality and subjective well-being are especially important for the most vulnerable communities particularly for elderly people.

Gerontological researches have created a considerable interest in recent years. The average life expectation has increased more than two times in the last 200 years. This means the number of senior people has also grown. It is important to study social and psychological aspects of the old age to ascertain the prospects of person's life after retirement. In late adulthood person faces a lot of social problems. The need of re-socialization after retirement and loss of numerous contacts with the reference group, the need to adapt to a new lifestyle become especially important. Social deprivation as a limit or complete lack of contact with society is a prerequisite for internal discomfort and significant personality changes of old person. These surely affect life priorities and the attitude to life in general.

To promote socialization of old people special homes are created where such people find home, care and attendance. One of the major functions of geriatric boarding house is preparing conditions that help to meet the varied needs of residents and maintaining the level of their social activity. Establishing psychological features of subjective life valuing among old-aged people may help to identify the new ways of giving people social and psychological assistance in going through stresses, adapting to new social conditions, self-development and longevity.

This research was carried out to study the peculiarities of life satisfaction among senior people living in geriatric homes. The aim of the work was to determine social and psychological components that form subjective well-being of 
elderly people in difficult social circumstances for better understanding of their personalities and the ways of granting them social-psychological support.

According to the aim the following tasks were put forward:

1. While analysing the problem of subjective well-being and the social and psychological features of old age to adjust the place of subjective life quality evaluation of senior people in social adaptation conditions.

2. To identify the main trends in life satisfaction and attitudes to life among geriatric home residents and those who live in their own homes.

3. To explore the role of life values and hardiness of old people in their life satisfaction.

The hypotheses of the study. It was assumed that due to limited social relationships the level of subjective well-being of geriatric residents is significantly lower than of people who have their own homes where they may find help and support of family. Possibly life satisfaction in old age is also related to high rates of physical and mental health, the values of hedonism and achievement.

\section{ANALYSIS OF THE PROBLEM OF SUBJECTIVE WELL-BEING IN LITERATURE}

The concept of well-being is widely used in psychology to describe a sphere of feelings and states of healthy people. However, this definition is too unspecific and does not show what factors lead to such a characteristic and how it can be studied. It seems advisable to distinguish only a part of well-being - its subjective components, the way a person thinks of his or her state. That is why this article concentrates on discussing the problem of subjective well-being or life satisfaction.

The term "satisfaction" is considered as subjective assessment of certain objects, activities and living conditions, life in general, relationships with people, attitudes to others and self-attitude. It determines many actions, different kinds of activity and behaviour - everyday, economical, political and others. Satisfaction with life effects mood, mental state, psychological stability. Usually this phenomenon is very simplified, just like some evaluation that a person gives to some situation. In fact it also includes a wide spectrum of feelings of the person's subjective well-being.

Categories of happiness, quality of life and well-being are close to the concept. They are often used interchangeably but there are still some semantic differences.

Happiness is a phenomenon that belongs to the existential aspect of the personality. It is very controversial and only partly has a psychological meaning. The feeling of happiness usually has cultural and ethnic differences, and level and quality of life influence only a little of this feeling. Psychological researches have proved strong correlations between happiness (tested with Oxford Happiness Questionnaire) and optimism level (like belief in better) (Argyle 2001, p. 9). After Viktor Frankl, happiness must be not an aim but a "by-product" of achieving the goal (Frankl 2006, p. 56).

Well-being is usually selected by researchers as the most constructive. It is included within the definition of health by WHO. By the way, experts of WHO think 
well-being is determined more by self-esteem and feeling of belonging to social group, realization of person's potential than by biological functions.

In the second half of twentieth century there were two approaches in researching well-being. The hedonistic approach determined personal well-being as achieving pleasure and avoiding displeasure (not only physical but also achieving goals). Their opponents - eudemonists who were psychologists of humanistic, existential, positive schools - understood well-being as self-fullness of human life in concrete circumstances and conditions (Ryff 1989, pp. 1069-1081).

Thus, the notion of well-being involves a combination of objective indicators of human well being - health, financial stability, social status, etc. - and its subjective assessment, usefulness and necessity of these factors for a person (Horbal 2011, p. 102). The first component is quality of life as a set of physical, emotional, mental, intellectual and general cultural factors that determine a person's ability to function. This category contains objective dimensions of human well-being. The second component of well-being is called life satisfaction or subjective well-being (Figure 1).

\section{Fig. 1: Life satisfaction as a component of personal well-being}

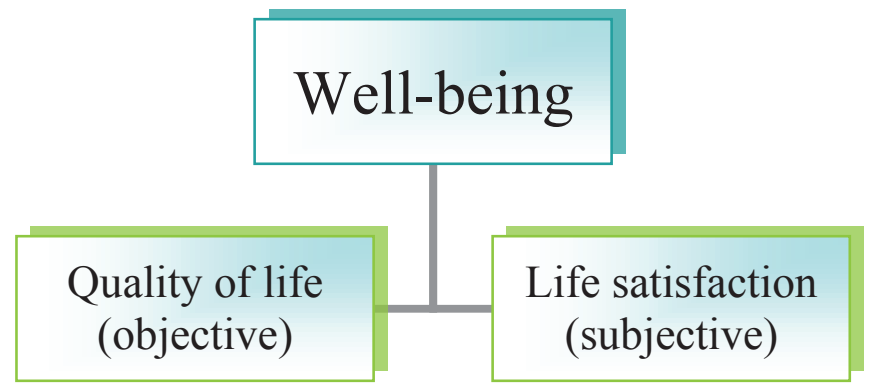

Source: Author`s compilation based on Ryff 1989, pp 1069-1081, Horbal 2011, p. 102.

If the concept of life satisfaction is examined in medicine as a factor of life quality, it applies to health, the impact of the disease process and treatment of certain aspects of patient's life and subjective well-being (Biswas-Diener, Diener 2006, p. 185). Psychologists connect subjective well-being with phenomena of self-actualization (Maslow 1987), social interest and relationships (Adler 1968), self-esteem (Rogers 1961) etc. Experience of subjective well-being depends on the needs, level of aspiration, requirements and expectations of life as well as the capabilities of their realization. Also it is considered through the prism of emotional life attitude, mainly attitude to referent people and their attitude to a person, social needs contentment and emotional self-attitude.

Being a subjective component of well-being life satisfaction may also be defined in certain aspects of life. Norman M. Bradburn's classic study giving a little attention to the fundamental meaning of well-being indicates five main spheres in which it is detected (Bradburn 1969). The measure of satisfaction within a social sphere depends on social status, current state of society, interpersonal relations, feeling of community. 
People who work are more satisfied with life, people whose lives are full of different events, who have family and friends. Satisfaction with work and marriage has been studied most in this area. The most important in spiritual satisfaction are the feelings of belonging to wealth and to culture, understanding a sense of life, faith in something. Good physical health and bodily comfort are basic in satisfaction with physical health. Satisfaction with the material side of life depends on having a person in his/ her home, nutrition, relaxation, feeling of full security, stability, material wealth. This component isn't unique: it was proved that poor residents of Calcutta hardly associate life satisfaction with the level of their own income (Biswas-Diener, Diener 2006, p. 196). Finally, psychological life satisfaction involves coordination of mental processes and functions, a sense of integrity, inner balance, psychological health.

These components always interact with each other but they aren't the only ones. The structure of life satisfaction may also contain a lot of other areas such as cultural, ethnic, sexual, educational (Diener, Diener, Diener 1995, p. 821); (Hall 1976, p. 47). Michael Argyle says life satisfaction may also involve comparing of today life with previous experience and life of other people, actual emotional state, adaptation to the situation etc (Argyle 2001).

Thus, the problem of subjective well-being is very real in social, economic, spiritual, moral aspects of a modern person's life. Satisfaction with life is the subjective component of human well-being and is determined by numerous personal and social factors. So it seems to be important to study the factors that determine subjective well-being of senior people especially of those who suffer from lack of social relationships.

\section{PSYCHOLOGICAL PECULIARITIES AND LIFE SATISFACTION IN OLD AGE}

One of the typical demographic features of nowadays world is that populations are getting older. That is why issues about old people become more important. Distinguishing a period of gerontogenesis is explained by a complex of social, economical, biological and psychological factors. Obsolescence is a basic universal biological process but it is realized in concrete social and cultural circumstances and leads to physical and psychological changes. Psychologists study the peculiarities of the elderly person's inner world, his or her needs, motives, emotional reactions for ensuring a happy late adulthood.

Senility is the final period in a person's development. There appear aging features that manifest themselves in appearance, low vital activity, limited physical resources, decreasing power and mobility of mental processes (mental obsolescence). Physical weakening also expresses itself in narrowing of interests, passivity, mental fading etc.

There is no single view about when old age begins. International age classification proposes to start late adulthood for women from the age of 50-55, for men from the age of 60 years (Burnside 1979, p. 551). After Grace J. Craig late adulthood for both sexes stats at 60 . Considering the age of geriatric residents we follow the last concept (Craig, Baucum 2002). 
Psychologists underline different indicators of subjective well-being in late adulthood. G. Craig notices such a qualifier as satisfaction with job. On the one hand, it shows whether a person had realized his or her opportunities during the employment, on the other hand, for those who concentrated only on the work it is not easy to get used to the new life after retirement (Craig, Baucum 2002, p. 772). A correlation was also proved between subjective well-being and subjective age: old people who feel younger than their real passport age indicates are more satisfied with life (Stephan, Caudroit, Chalabaev 2011, pp. 428-436).

Emotional factors are also important. The interpersonal relationships might be affected by the changes in the emotional sphere - uncontrolled increasing of affective reactions, predisposition to the gratuitous sadness, tearfulness, eccentricity, decreasing of sensitiveness and possibility to get out of the difficult situations etc. (Ермолаева 2002, pp. 153-155). The amount of granted and received emotional support decreases with the age because senior people become more selective in the process of choosing social contacts (Sener 2011, pp. 79-88). Positive emotions that elderly people feel while communicating with others influence cognitive functioning, promote preservation of physical health, prevent premature death (Charles, Carstensen 2010, pp. 383-409).

Among the different aspects of old-aged personality the leading kind of activity and social development situation are very important. Alexander Liders considers the main activity of senior people is a special "inner work" directed towards accepting a way of life, comprehending present and past, providing healthy senility (Лидерс 2000, pp. 6-11). However, a social situation that the old person lives in plays an important role in his or her personal development and subjective wellbeing. Ukrainian researcher Natalia Panina found that social contacts are the most important for a normal adaptation of a retired person (Панина 1982, pp. 156-160).

Researchers have studied social and psychological aspects of different periods of late adulthood. Social situation changes when the senility deepens, a person gets less opportunities to interact with other people beyond their family. The preretirement period is characterized by waiting for the retirement, people at this age contact a lot with co-workers in an attempt to educate a meaningful change. The first years after retirement are important for getting used to the new social role. Contacts with colleagues are mainly replaced with the communication with relatives. Henceforth the contacts with close people change, they begin to be perceived less intimate and more generalised. All activity of elderly people this time is focused on the desire to feel themselves needed in society. If after 75-80 years a person has no serious problems with life psychologists call him or her centenarian. Specificity of communication with relatives at this period is characterized by their pride for the centenarian, this also helps a senior person to widen the circle of interaction (Пряжников 1996, pp. 141-175).

Thus, alongside lots of stereotypes about late adulthood as a period of "fading" and "dying away" it is important to study aging characteristics of such people because many peculiarities of old age depend on them. Moreover late adulthood plays an important role the in general life cycle of every person.

A special role of interaction between husband and wife in late adulthood is emphasized. These relationships are ambiguous. On the one hand, marriage 
determines a circle of communication, gives support, on the other hand, the aggravation of personal features, the reduction of social control complicate the interaction of a couple (Craig, Baucum 2002, p. 775). A great importance of social interest in old age is proved by many psychologists. It is related to feelings of belonging to the group, of comfort in contacts with others, of similarity with people, belief that every person is good inside, opportunity to recognize own weakness, absence of fear to make a mistake and optimism. Social interest gives a person a possibility to use knowledge in helping other people, to take part in a group's life, to admit other peoples' thoughts, to search compromises for general advantage etc (Абрамова 1999, с. 632). Social interest together with attention to senior personality are important factors in ensuring good contacts with people and self-attitude, proper life in old age. The disturbance of social relationships in late adulthood leads to losing the common life rhythm that causes stresses and poor health.

The crisis of late adulthood is typical for this time. Erik Erikson called it a crisis of self-integration (Erikson 1986). It ends successfully when after analyzing life a person feels satisfied with it, sees its meaning, and perceives all realized opportunities and puts forward new aims. The peculiarities of the crisis are determined by the end of crisis in the period of retirement. The last is caused by the need of getting used to a new social role and usually moves into another. A great number of post-soviet researchers of late adulthood crisis (Моргун 1984, Анциферова 1994, Хухлаева 2002, Малкина-Пых 2005 et al.) follow a thought that it is socially determined, depends on the quality of relationships of senior people with others. Thus, social interaction is an important part of old person's life and problems in this sphere might play a big role in subjective well-being.

Retirement, death of husband or spouse and removal to the geriatric home are considered to be the main determinants of early death. The problem of living in a geriatric home is related to the phenomenon of social deprivation. It is considered as a loss of something because of some important frustration of needs. When mental needs are not satisfied the mental deprivation is present. Social deprivation is one of the kinds of mental deprivation, a limit or complete lack of contacts with society caused by forced or voluntary isolation from the rest of people (Алексеенкова 2009, p. 53).

Late adulthood is a period determined by biological, mental and social phenomena. That is why the removal to the geriatric home and changing of familiar life situations may be a stress for the elderly person and may cause problems with physical and mental health. Social deprivation may be dangerous for such people stipulating inner discomfort. The aim of this article is to study how social and psychological peculiarities are connected with subjective feelings of life satisfaction and to find out ways of adapting senior people to life in geriatric homes most effectively.

\section{PARTICIPANTS AND RESEARCH METHODS}

In order to investigate psychological peculiarities of life satisfaction among people who live in geriatric homes empirical research was provided. Two groups were formed. The main group contained 28 elderly people (62-88 years old) who live in a L'viv geriatric home. In control group there were 28 old-aged people who 
live in their own houses. Each group consists of 8 men and 20 women because nearly a third of geriatric residents are male. All respondents have no cognitive disorders.

For diagnosis of human life satisfaction The Satisfaction With Life Scale (Diener 1985, pp. 71-75) was used. The modified questionnaire Semantic differential was used to identify attitudes to life. To determine the components of quality of life The questionnaire SF-36 by John E. Ware (Ware, Sherbourne 1992, pp. 473-483) was used. The questionnaire of life values by Shalom H. Schwartz (Schwartz 1994, pp. 19-45) and The test of hardiness by Salvatore R. Maddi (Maddi 1998, pp. 320340) were taken to study other psychological peculiarities of elderly people.

Statistical data processing was performed using Statistica 8.0 with descriptive statistics, parametric and nonparametric criteria for comparing the level of the studied traits in different groups (t-test independent by groups, Mann-Whitney U-test, Oneway ANOVA, Kruskel-Wallis ANOVA \& Median test), correlation analysis, multivariate exploratory techniques (factor, cluster and discriminant analysis).

Such outcomes were obtained:

1. The results of the research showed that the general level of life satisfaction among elderly people is low (16.4 points out of 35 among geriatric home residents and 19 points among people who live in their own houses). Different spheres of the older person's life (bad material conditions, worsening of health, close death, changes of social status and understanding of all those difficulties) play an important role in determining life satisfaction and these indicators are not high enough to ensure the high subjective well-being. We suggest the general level of subjective well-being in studied older people is low primarily due to difficulties with adaptation to the new social role.

2. Comparing general levels of life satisfaction between the geriatric residents and people from their homes no significant difference was determined $(p<0.05)$. However, the comparative analysis showed that one of the components of it - the feeling of being satisfied - is higher among people who live in their own houses $(p<0.05)$ (Figures $2 a, 2 b)$. When they are asked directly whether they like their life or not they are more likely to give more positive answers then geriatric home residents. Despite this, the questionnaire showed that elderly people have many arguments to describe their life negatively no matter what the social conditions they live in (there was found no difference in answers about satisfaction with life conditions, wishes to change something in the past etc.).

On the other hand, the observed difference in subjective well-being proves social factors are important. In geriatric homes people have no opportunity to control their lives, to support the needed social contacts. This is reflected in their psychological states, causes inner discomfort, low subjective assessment of life. Social support for families increases life satisfaction of people who live in their own houses. 
Fig. 2a: General level of life satisfaction among geriatric residents and people who have their own houses.

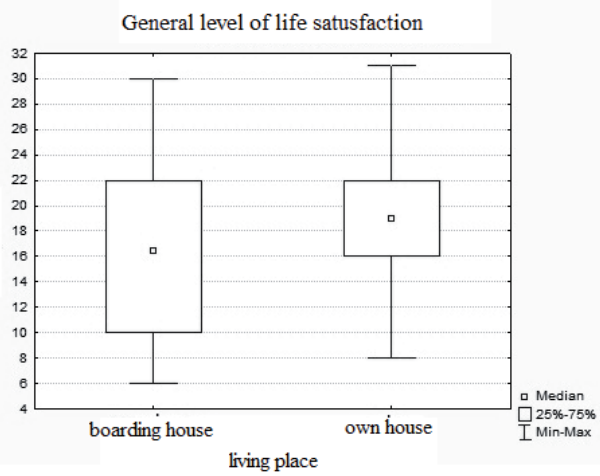

Fig. 2b: “Feeling of being satisfied with life" level among geriatric residents and people who have their own houses.

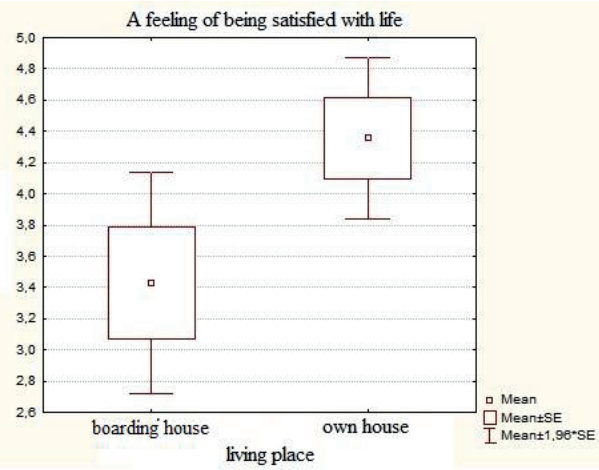

Source: prepared by author.

3. In order to check the second part of the research hypothesis the correlation analysis for the results of all respondents was made. We revealed that life satisfaction is tightly related to psychological $(\mathrm{r}=0.44)$ and mental $(r=0.42)$ health. The absence of serious inner conflicts is important for person's feeling well and being satisfied with life. At the same time it was not proved that physical health pays a big role in ensuring subjective well-being of senior people $(\mathrm{r}=0.01)$. The physical component of life satisfaction is not the main one in late adulthood.

Psychological peculiarities of satisfaction with life in both groups are presented by high hardiness $(r=0.67)$. Senior people feel satisfied when they are able to perceive life problems more easily. That is why they do not pay so much attention to hard conditions of life, bad financial state, worsening of health etc. It was also found that high rates of emotional $(\mathrm{r}=0.27)$ and social $(\mathrm{r}=0.38)$ functioning relate to high life satisfaction. Moreover people in old age feel more happy when their relatives come to see them often $(\mathrm{r}=0.27)$. The hypothesis was only partly proved: mental health together with opportunities of social contacting with people (but not with physical being well) are the main components of life satisfaction of older people.

4. After studying the correlations between life satisfaction and different psychological peculiarities separately in studied groups there were the structures of subjective well-being for geriatric residents and people from their own houses. Interestingly this time it was found that there were three groups of components that form the structure: psychological, social and physiological. Life satisfaction among geriatric residents (Figure 3 ) is determined by good psychological health $(\mathrm{r}=0.64)$ as a sense of inner harmony, high hardiness $(\mathrm{r}=0.78)$ as an ability to resist stress and paying less attention to the difficulties, importance of hedonistic satisfaction of needs $(r=0.41)$, low spirituality 
$(\mathrm{r}=-0.39)$, opportunity to contact with people $(\mathrm{r}=0.58)$, feeling no physical pain $(\mathrm{r}=-0.47)$. On the whole, life satisfaction in this group is stipulated primarily with personal characteristics that form the stability of the inner world.

Fig. 3: The structure of life satisfaction of a geriatric resident.

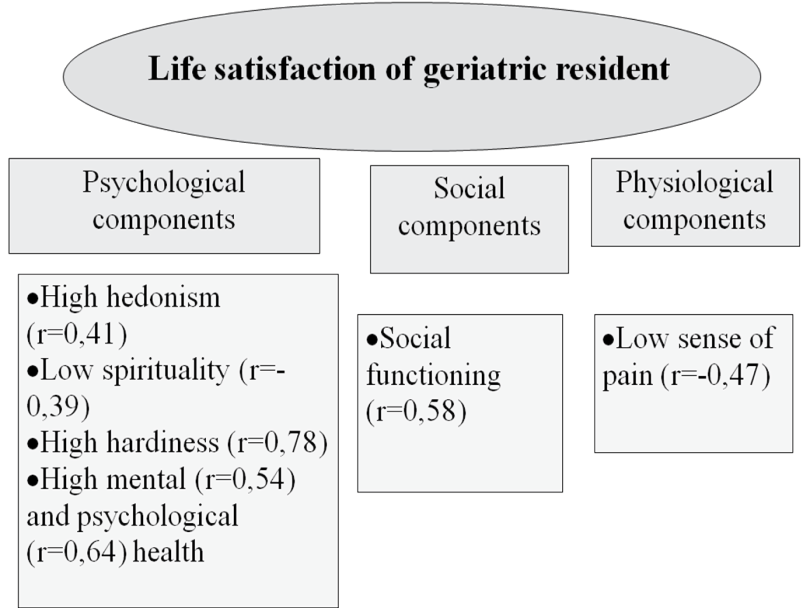

Sources: prepared by author.

By contrast, the structure of life satisfaction of elderly people who own their own houses contains some different features. It is important to interact actively with relatives $(\mathrm{r}=0.39)$, to be involved in society $(\mathrm{r}=0.50)$, to be capable of emotional interaction $(\mathrm{r}=0.40)$, perception and expression of feelings. Values motivate these people to activity, give rise to achieve something new $(\mathrm{r}=0.46)$, to search new experience $(\mathrm{r}=0.40)$, independence in their actions $(r=0.38)$. Finally, the physiological component of life satisfaction is not just avoiding pain, but opportunity to be physically healthy in general $(\mathrm{r}=0.53)$ and to keep house $(\mathrm{r}=0.42)$. This shows that people try to simplify the late adulthood crisis by staying socially necessary.

Thus, the hypothesis of the research was partially confirmed. The level of life satisfaction in both research groups is closely related to values of hedonism and achievement: oriented towards searching enjoyment and reaching new goals old people feel more subjective well-being. Good mental health leads to life satisfaction for the geriatric residents, physical health is more important for the high subjective well-being of people living in their own homes.

5. Investigation of attitudes to life of old people determined three dimensions of attitude: optimism-pessimism as tendency to perceive life as happy or sad, light or dark, friendly or hostile etc, idealism-realism as a tendency to take life as a simple or complicated, regulated or chaotic, cheap or expensive, quiet or bustling, etc, and passivity-activity in relation to existence as a slow or rapid, dependent or independent, lifeless or vigorous. Geriatric residents 
perceive life more realistic and passively, older people who have their house show opposite results $(\mathrm{p}<0.05)$. The level of optimism-pessimism in both groups is approximately the same, undefined medium level ( $p>0.05)$. So, people who have more opportunities for social interactions see their life more positively. They are closer to the ego-integration while resolving personal conflict in geriatric residents is complicated by negative attitudes to life. As a result, they experience painfully their present and previous situation, being unable to sum up positively results of their own life.

\section{CONCLUSIONS}

The article was dedicated to the psychological components of subjective well-being of old people living in geriatric homes. During the survey the features of attitudes to life and life satisfaction of senior people which by the circumstances in the period of late adulthood were living in special institutions, were analyzed. Their individual psychological characteristics related to subjective well-being were also studied.

The results of the research argue that there are some differences in life satisfaction of geriatric residents, compared to the studied older people living in their own houses. However, significant differences were traced not simply in the level of subjective life evaluation but in social and psychological components that form it. It was found that the level of life satisfaction is linked with numerous personal characteristics, although the availability of social interactions in old age is very important.

For high subjective well-being residents of geriatric homes need a sense of internal harmony, effective coping strategies and an ability to interact with people outside the institution. Nevertheless, subjective well-being of the inhabitants of the geriatric home is lower than of people living in their own houses. Increasing of life satisfaction will positively improve both the physical and mental state of such people.

Geriatric homes in our country are mainly concentrated on taking care of the physical well-being of their residents. Care and nursing are important but not the only needs of elderly people. Their subjective well-being also consists of numerous social and psychological components. That is why an inference should be made about the need for restructuring of such institutions. Further work in this area is appropriate in two main directions. Firstly, the openness of geriatric homes especially on cooperation with relatives and other close people of the residents will promote their higher subjective well-being and better adaptation to the difficult social conditions. Certainly an ability to make own decisions should be given to the geriatric residents, it will make them feel more active, increasing the overall level of subjective well-being. Secondly, a system of psychological support of senior people should be perfected. The interaction with a psychologist is able to provide better self-understanding and to help in forming individual features for effective stress-coping and self-actualization.

\section{BIBLIOGRAPHY}

Adler A. (1968), The Practice and Theory of Individual Psychology, Littlefield Adams, Towota, NJ. Argyle M. (2001), Psychology of Happiness, Routledge, London.

Bilsky W., Schwartz S. H. (1994), Values and personality, "European Journal of Personality”, 8. 
Biswas-Diener R., Diener E. (2006), Subjective well-being of the homeless, and related lessons for happiness, "Social Indicators Research", 76.

Bradburn N. M. (1969), The structure of psychological well-being, Aldine, Chicago.

Burnside I. M. (1979), The later decades of life: Research and reflections, [in:] Burnside I. M., Ebersole P., \& Monea H.E. (eds.), Psychosocial caring throughout the life span, McGraw-Hill, New York.

Burnside I. M., Ebersole P., \& Monea H.E. (1979) (eds.), Psychosocial caring throughout the life span, McGraw-Hill, New York.

Charles S. T., Carstensen L. L. (2010) Social and emotional aging, "Annual Review of Psychology", 61.

Craig G. J., Baucum D. (2002), Human development, Prentice Hall, New Jersey.

Diener E. (1985), The Satisfaction With Life Scale, "Journal of Personality Assessment", 49/1.

Diener E., Diener M., Diener C. (1995), Factors predicting the subjective well-being of nations, "Journal of Personality and Social Psychology", 69.

Erikson E. H., Erikson J. M., Kivnick H. Q. (1986), Vital involvement in old age, Norton, New York.

Frankl V. (2006), Man's Search of Meaning, Beacon Press, Boston.

Friedman S.H. (1998) (ed.), Encyclopedia of mental health, Academic Press, San Diego, CA.

Hall J. (1976), Subjective measure of quality of life in Britain : 1971 to 1975 - some developments and trends, "Social Trends", 7 .

Horbal I. (2011), Theoretical analysis of the problem of satisfaction with life in modern psychology, "Психологічні проблеми сучасності: Тези VIII науково-практичної конференції студентів та молодих вчених", Львів.

Maddi S. R. (1998), Dispositional hardiness in health and effectiveness, [in:] Friedman S.H. (ed.), Encyclopedia of mental health, Academic Press, San Diego, CA.

Maslow A. (1987), Motivation and Personality, $3^{\text {rd }}$ Ed., Addison-Wesley, New York.

Rogers C. (1961), On becoming a person: A therapist's view of psychotherapy, Houghton Mifflin, Boston.

Rokeach M. (1973), The nature of human values, Free Press, New York.

Ryff C. D. (1989), Happiness is everything, or is it? Explorations on the meaning of psychological well-being, "Journal of Personality and Social Psychology", 57/6.

Schwartz S. H. (1994), Are there universal aspects in the content and structure of values?, "Journal of Social Issues", 50.

Schwartz S. H., Bilsky W. (1987), Toward a universal psychological structure of human values, "Journal of Personality and Social Psychology", 53.

Sener A. (2011), Emotional Support Exchange and Life Satisfaction, "International Journal of Humanities and Social Science", $1 / 2$.

Stephan Y., Caudroit J., Chalabaev A. (2011), Subjective health and memory self-efficacy as mediators in the relation between subjective age and life satisfaction among older adults, "Aging \& Mental Health", 15/4.

Ware J.E., Sherbourne C.D. (1992), The MOS 36-item Short-Form Health Survey (SF-36): Conceptual framework and item selection, "Medical Care", 30.

Абрамова Г. С. (1999), Возрастная психология, Деловая книга, Екатеринбург.

Алексеенкова Е. Г. (2009), Личность в условиях психической депривации: Учеб. пособие, Питер, Санкт-Петербург.

Анщыферова Л. И. (1994), Новые стадии поздней жизни: время теплой осени или суровой зимы? “Психологический журнал", 15/3.

Куликов Л. В. (2000), Детерминанты удовлетворенности жизнью, “Общество и политика", Санкт-Петербург.

Лидерс А. Г. (2000), Кризис пожилого возраста: гипотеза о его психологическом содержании, “Психология зрелости и старения", 2.

Малкина-Пых И. Г. (2005), Возрастные кризисы: Справочник практического психолога, Эксмо, Москва.

Моргун В.Ф., Ткачева Н.Ю. (1981), Проблема периодизации развития личности в психологии, Издательство МГУ, Москва. 1981.

Панина Н. В. (1982), Роль семьи в проведении досуга пенсионеров и их соииальной адаптаици, “Геронтология и гериатрия: Пожилой человек, медицинская и социальная помощь", Киев.

Пряжников Н.С. (1996), Профессиональноеи личностное самоопределение, Изд-во Института практической психологии, Москва.

Хухлаева О. В. (2002), Психология разбития: молодость, зрелость, старость: Уиебное пособие, Академия, Москва.

Шамионов Р. М. (2004), Психология субъективного благополучия личности, Саратов. 